\title{
Codependency Addiction: Stages of Disease and Recovery
}

\author{
Darlene Lancer* \\ Licensed Marriage and Family Therapist, USA
}

Submission: June 15, 2017; Published: June 21, 2017

*Corresponding author: Darlene Lancer, Licensed Marriage and Family Therapist, USA, Email: info@darlenelancer.com

\section{Short Communication}

Codependency has been referred to as "relationship addiction" or "love addiction." The focus on others helps to alleviate our pain and inner emptiness, but in ignoring ourselves, it only grows. This habit becomes a circular, selfperpetuating system that takes on a life of its own. Our thinking becomes obsessive, and our behavior can be compulsive, despite adverse consequences. Examples might be calling a partner or ex we know we shouldn't, putting ourselves or values at risk to accommodate someone, or snooping out of jealousy or fear. This is why codependency has been referred to as an addiction. In 1956, it decided that addiction was a disease, and in 2013 also named obesity a disease. A prime motivation in both cases was to de-stigmatize these conditions and encourage treatment.

\section{Is Codependency a Disease?}

In 1988, psychiatrist Timmen Cermak suggested that codependency is a disease noting the addictive process. Psychiatrist and doctor of internal medicine, Charles Whitfield , described codependence as a chronic and progressive disease of "lost-selfhood" with recognizable, treatable symptoms- just like chemical dependence. I agree with Dr. Whitfield, and in Codependency for Dummies refer to codependency as a disease of a lost self. In recovery, we recover our selves.

Codependency is also characterized by symptoms that vary on a continuum similar to those associated with drug addiction. They range from mild to severe and include dependency, denial, dysfunctional emotional responses, craving and reward (through interaction with another person), and inability to control or abstain from compulsive behavior without treatment. You increasingly spend time thinking about, being with, and/ or trying to control another person, just as a drug addict with a drug. Other social, recreational, or work activities suffer as a result. Finally, you might continue your behavior and/ or the relationship, despite persistent or recurring social or interpersonal problems it creates.

\section{Stages of Codependency}

Codependency is chronic with enduring symptoms that are also progressive, meaning that they worsen over time without intervention and treatment. In my opinion codependency begins in childhood due to a dysfunctional family environment. But children are naturally dependent, it cannot be diagnosed until adulthood, and generally begins to manifest in close relationships. There are three identifiable stages leading to increasing dependence on the person or relationship and corresponding loss of self-focus and self-care.

\section{Early Stage}

The early stage might look like any romantic relationship with increased attention and dependency on your partner and desire to please him or her. However, with codependency, we can become obsessed with the person, deny or rationalize problematic behavior, doubt our perceptions, fail to maintain healthy boundaries, and give up our own friends and activities.

\section{Middle Stage}

Gradually, there's increased effort required to minimize painful aspects of the relationship, and anxiety, guilt, and selfblame set in. Over time, our self-esteem lessens as we compromise more of ourselves to maintain the relationship. Anger, disappointment, and resentment grow. Meanwhile we enable or try to change our partner through compliance, manipulation, nagging, or blaming. We might hide problems and withdraw from family and friends. There may or may not be abuse or violence, but our mood worsens, and obsession, dependence, and conflict, withdrawal, or compliance increase. We might use other addictive behaviors to cope, such as eating, dieting, shopping, working, or abusing substances.

\section{Late Stage}

Now the emotional and behavioral symptoms begin to affect our health. We may experience stress-related disorders, such 
as digestive and sleep problems, headaches, muscle tension or pain, eating disorders, TMJ, allergies, sciatica, and heart disease. Obsessive-compulsive behavior or other addictions increase, as well as lack of self-esteem and self-care. Feelings of hopelessness, anger, depression, and despair grow.

\section{Recovery}

The good news is that the symptoms are reversible when a codependent enters treatment. People don't generally seek help until there's a crisis or they're in enough pain to motivate them. Usually, they aren't aware of their codependency and may also be in denial about someone else's abuse and/or addiction Recovery begins with education and coming out of denial. Reading about codependency is a good beginning, but greater change occurs through therapy and attending a Twelve-Step program, such as Al-Anon, CoDA, Nar-Anon, Gam-Anon, or Sex and Love Addicts Anonymous.

In recovery, you gain hope and the focus shifts from the other person to yourself. There are early, middle, and late stages of recovery that parallel recovery from other addictions. In the middle stage, you begin to build your own identity, selfesteem, and the ability to assertively express feelings, wants, and needs. You learn self-responsibility, boundaries, and selfcare. Psychotherapy often includes healing PTSD and childhood trauma. In the late stage, happiness and self-esteem doesn't depend on others. You gain the capacity for both autonomy and intimacy. You experience your own power and self-love. You feel expansive and creative, with the ability to generate and pursue your own goals.

Codependency doesn't automatically disappear when a person leaves a codependent relationship. Recovery requires ongoing maintenance, and there is no perfect abstinence. After a number of years in treatment, the changes in thinking and behavior become increasingly internalized, and the tools and skills learned become new healthy habits. Still, codependent behavior can easily return under increased stress or if you enter into a dysfunctional relationship. Perfectionism is a symptom of codependency. There is no such thing as perfect recovery. Recurring symptoms merely present ongoing learning opportunities!

\section{Biography of the Author}

Darlene Lancer is a Licensed Marriage and Family Therapist and expert on relationships and codependency. She's the author Conquering Shame and Codependency: 8 Steps to Freeing the True You and Codependency for Dummies and six eBooks, including: 10 Steps to Self-Esteem, How To Speak Your Mind Become Assertive and Set Limits, How to be Assertive Breakup Recovery, "I'm Not Perfect - I'm Only Human" - How to Beat Perfectionism, Dealing with a Narcissist: 8 Steps to Raise SelfEsteem and Set Boundaries with Difficult People, Spiritual Transformation in the Twelve Steps, and Freedom from Guilt and Blame - Finding Self-Forgiveness, Codependency's Recovery Daily Reflections, How to Raise Your Self-Esteem also available on Amazon. Ms. Lancer has counseled individuals and couples for 30 years and coaches internationally. She's a sought after speaker in media and at professional conferences. Her articles appear in professional journals and Internet mental health websites, including on her own, www.whatiscodependency.com, where you can get a free copy of " 14 Tips for Letting Go." Follow her on Twitter @darlenelancer and Facebook. You can also listen and watch on Soundcloud, Clyp, and Youtube.

\section{Your next submission with Juniper Publishers} will reach you the below assets

- Quality Editorial service

- Swift Peer Review

- Reprints availability

- E-prints Service

- Manuscript Podcast for convenient understanding

- Global attainment for your research

- Manuscript accessibility in different formats

( Pdf, E-pub, Full Text, Audio)

- Unceasing customer service

Track the below URL for one-step submission https://juniperpublishers.com/online-submission.php 